\title{
Keadilan dan Advokasi sebagai Panggilan Gereja dalam Konteks Kehidupan Kaum Buruh
}

\author{
Ravanelly Fabrizio Gabriel \\ Universitas Kristen Indonesia Maluku \\ ravanellygabriel1405@gmail.com
}

\begin{abstract}
This article aims to analyze several issues of injustice, which can threaten the welfare of port workers and build an advocacy theology as a form of defending the rights of their lives. These problems are related to the distribution of basic wages and overtime wages, as well as social benefits. The research uses a practical theological model with four phases, namely descriptive empirical task, interpretive task, the normative task, and the pragmatic task. It has a qualitative method with interview techniques, observations, documentation, and library studies. The results of study found that the existence of port workers in Ambon was in an unfair and prosperous situation. In addressing the issue, the Maluku Protestant Church was called to carry out advocacy actions by referring to theological foundations related to God's justice. Acvocacy actions carried out in the church context can be based on social values with social dimensions such as truth, welfare, justice, and transparency in everything that is done. In addition, the Maluku Protestant Church can establish cooperation with govermment and followers of other religions to seek prosperity, uphold justice and truth for all members of the workers.
\end{abstract}

Keywords: advocacy; injustice; Maluku Protestant Church; workers

\begin{abstract}
Abstrak: Artikel ini bertujuan menganalisis masalah ketidakadilan yang dapat mengancam kesejahteraan hidup kaum buruh pelabuhan dan membangun teologi advokasi sebagai bentuk pembelaan hak-hak hidup mereka. Masalah tersebut berkaitan dengan pembagian upah pokok dan upah lembur kerja, serta tunjangantunjangan sosial. Penelitian ini menggunakan model teologi praktis dengan empat tahapan, yakni descriptive empirical task, interpretive task, the normative task, dan the pragmatic task. Didalamnnya terdapat metode kualitatif dengan teknik wawancara, observasi, dokumenasi, dan studi pustaka. Hasil penelitian menemukan bahwa eksistensi kaum buruh pelabuhan di Ambon berada pada situasi yang tidak adil dan sejahtera. Dalam menyikapi persoalan tersebut, Gereja Protestan Maluku terpanggil untuk melakukan tindakan advokasi dengan mengacu pada landasan-landasan teologis terkait keadilan Allah. Tindakan advokasi yang dilakukan dalam konteks bergereja dapat didasarkan pada nilai-nilai keagamaan yang berdimensi sosial seperti kebenaran, kesejahteraan, keadilan dan transparasi terhadap segala sesuatu yang dilakukan. Selain itu, Gereja Protestan Maluku dapat membangun kerja sama dengan pemerintah dan pemeluk agama lain untuk mengupayakan kesejahteraan, menegakkan keadilan dan kebenaran bagi seluruh anggota kaum buruh.
\end{abstract}

Kata Kunci: advokasi; buruh; Gereja Protestan Maluku; ketidakadilan

\begin{tabular}{llll}
\hline Article History : & Received: 16-07-2019 & Revised: 22-10-2019 Accepted: 15-12-2019
\end{tabular}




\section{Pendahuluan}

Penelitian tentang advokasi dalam lingkup teologi Kristen masih sangat kurang. Ada beberapa penelitian yang ditemukan terkait advokasi Kristen, yakni Magdalene.co sebagai Media Advokasi Perempuan; Berkubang dalam Lumpur, Bekerja Bersama Orang Miskin" Wajah Keterlibatan Sosial Gereja Ganjuran; dan Framing Gerakan Forum Masyarakat Minangkabau dan Advokasi Kebijakan Investasi di Kota Padang. ${ }^{1}$ Penelitian-penelitian tersebut merujuk pada tindakan pembelaan atas hak hidup sesama manusia. Hal ini sedikit berbeda dengan tindakan advokasi yang dilakukan oleh Gereja Protestan Maluku. Pihak Majelis Pekerja Harian Sinode GPM menyatakan bahwa tindakan advokasi yang dilakukan selama ini lebih merujuk pada advokasi ekologi dan bukan advokasi manusia. ${ }^{2}$ Oleh sebab itu, melalui tulisan ini penulis menyuarakan tindakan advokasi gereja terhadap masalah kemanusiaan dengan menyoroti sistem kerja kaum buruh di Pelabuhan Ambon.

Mekanisme kerja yang dilakukan oleh kaum buruh ialah menggunakan sistem kerja bergilir dari kelompok pertama hingga yang terakhir. Sejauh ini, pekerjaan yang ditekuni oleh kaum buruh mendapat pengakuan bahwa mereka tidak memperoleh upah kerja secara merata. Hal ini berarti bahwa telah terjadi ketidakadilan dalam pembagian upah kerja. Ketidakadilan yang dialami oleh kaum buruh berawal dari relasi kekuasaan antara pemberi upah atau pemilik modal dengan kaum buruh yang digambarkan sebagai superior dan inferior. Dalam relasi ini, kaum buruh dilihat sebagai objek yang dipakai sebagai "alat peras" penguasa dan menciptakan ketidakadilan, terutama pada pemberian upah kerja. Pada saat pembagian upah kerja terdapat beberapa langkah yang harus dilakukan. Langkah-langkah tersebut memiliki kaitan dengan cara menghitung tarif upah untuk melakukan pembagian yang merata kepada kaum buruh. Akan tetapi, pembagian tersebut sudah dilakukan dari tangan yang pertama ke tangan yang berikutnya, sehingga pembagian upah menjadi tidak merata dan tidak sesuai dengan tenaga yang sudah dikeluarkan. Hal ini biasanya ditemukan ketika terjadi perhitungan upah antara mandor dengan kaum buruh.

Pekerjaan bongkar muat di pelabuhan Ambon dilakukan sebanyak dua kali dalam sebulan. Durasi kerja di setiap kali bongkar muat berlangsung selama 6-7 jam. Akan tetapi, terkadang pekerjaan tersebut berlangusng melebihi waktu kerja yang ditetapkan. Dalam pembagian upah kerja, kaum buruh memperoleh pembayaran sebesar Rp. 1.418.000 per bulan. Upah tersebut tidak sebanding dengan pekerjaan yang dilakukan melebihi waktu yang ditentukan. Selain itu, upah yang diberikan juga tidak

\footnotetext{
${ }^{1}$ Eni Maryani dan Justito Adiprasetio, “Magdalene.co sebagai Media Advokasi Perempuan” Jurnal Ilmu Komunikasi Vol. 14 No. 1 (Juni 2017): 111-124; Wira Hospita, Aidinil Zetra dan Afrizal, "Framing Gerakan Forum Masyarakat Minangkabau dan Advokasi Kebijakan Investasi di Kota Padang" KELOLA: Jurnal Ilmu Sosial Vol. 1 No. 1 (Juni 2018): 57-69.

${ }^{2}$ Hasil Wawancara dengan WP (MPH Sinode GPM) pada tanggal 01 Maret 2019.
} 
setara dengan Upah Minimum Kota Ambon sebesar Rp. 2.436.077.3 Dengan demikian, kebutuhan hidup kaum buruh belum dapat terpenuhi secara utuh untuk memperoleh kehidupan yang layak. Hal ini disebabkan oleh kemampuan penguasa yang menguasai kelompok kaum buruh dan berimbas pada penyiksaan secara fisik maupun psikis mereka yang mungkin saja dirasakan namun tidak ditunjukan secara langsung.

Tidak hanya terjadi pada proses pembagian upah kerja, tindakan ketidakadilan juga terjadi pada tunjangan hidup kaum buruh yang turut mempengaruhi kesejahteraan mereka. Hukum perburuhan menegaskan bahwa buruh berhak untuk memperoleh tunjangan kesehatan berupa bantuan pemeriksaan atau pengobatan di poliklinik. Apabila buruh tidak melakukan bongkar muat selama dua hari dengan alasan sakit, maka buruh tersebut berhak untuk memperoleh tunjangan sakit. ${ }^{4} \mathrm{Akan}$ tetapi, beberapa kaum buruh mengaku bahwa hal tersebut tidak sepenuhnya dirasakan oleh kaum buruh di pelabuhan Ambon. Tunjangan kesehatan yang diberikan kepada kaum buruh hanyalah berupa pemeriksaan sesaat di kantor kesehatan Pelabuhan Ambon. Pihak pelabuhan tidak memberi bantuan sepenuhnya kepada kaum buruh berdasarkan hukum perburuhan yang telah ditetapkan selama ini. Oleh sebab itu, sistem kerja yang dilakukan oleh kaum buruh mengalami ketidakadilan yang turut mempengaruhi pribadi mereka dan khususnya kinerja yang dimiliki.

Dalam perspektif teologi, isu ketidakadilan merupakan masalah iman. Orang Kristen terpanggil untuk hidup berdasarkan apa yang diimani. Hal ini berarti bahwa sikap iman yang harus ditempuh oleh orang Kristen dalam menyikapi isu ketidakadilan ialah solidaritas kepada mereka yang secara struktur diperlakukan tidak adil. Sikap tersebut merupakan wujud keikutsertaan gereja dalam hidup dan perutusan Yesus Kristus. ${ }^{5}$ Selain itu, orang Kristen diciptakan Allah sesuai dengan citra-Nya dan diberi tugas sebagai mitra-Nya. Sebagai citra Allah, maka seluruh umat manusia perlu dilayani oleh gereja. Dalam hal ini, konteks umat manusia digambarkan sebagai sosok yang dimarjinalkan seperti kaum buruh. Sehubungan dengan itu, pada tahun 2013 salah satu dokumen World Council of Churches yang membahas tentang migran menegaskan bahwa:

Semua orang diciptakan menurut citra Allah. Penghargaan atas martabat manusia dan harga setiap pribadi tanpa membedakan usia, kemampuan, etnisitas, jender, kelas, kebangsaan, ras dan agama adalah hal yang mendasar bagi iman kita. Iman mendorong kita untuk memastikan abhwa kehidupan manusia, keamanan fisik dan keselamatan pibadi dijamin dalam hukum dan lembaga-lembaga. ${ }^{6}$

\footnotetext{
${ }^{3}$ Keputusan Gubernur Maluku Nomor 186A Tahun 2018 tentang Penetapan Upah Minimum Kota Ambon Tahun 2019.

${ }^{4}$ Iman Soepomo, Pengantar Hukum Perburuhan (Jakarta: Djambatan, 1980), 143.

5 J. B. Banawiratma, Hidup Menggereja Kontekstual (Yogyakarta: Kanisius, 2000), 181-186.

${ }^{6} J a n$ Aritonang, dan Ateria Aritona, Mereka juga Citra Allah: Hakikat dan Sejarah Diakonia temasuk bagi yang Berkeadaan dan Berkebutuhan Khusus: Buruh, Migran dan Pengungsi, Penyandang Disabilitas, LGBT, (Jakarta: BPK Gunung Mulia, 2017), 6.
} 
Berdasarkan hal tersebut, maka orang Kristen dan khususnya gereja terpanggil untuk menjalankan misi Allah yang mendatangkan keadilan, kedamaian dan sejahtera demi keutuhan ciptaan. Gereja dan pihak pelabuhan Ambon merupakan dua institusi yang berbeda. Akan tetapi, gereja memiliki peran yang sangat penting untuk mengadvokasi persoalan-persoalan kemanusiaan yang meliputi tindakan ketidakadilan bagi kaum buruh khususnya para pekerja di Pelabuhan Ambon. Dengan kata lain, gereja bertanggung jawab untuk menyuarakan keadilan atas tindakan yang tidak adil. ${ }^{7}$

\section{Metode Penelitian}

Dalam penelitian ini penulis menggunakan model teologi praktis dari Richard R. Osmer dalam buku Practical Theology: An Introduction yang membagi empat tahapan untuk menganalisis di bidang teologis praktis, yakni pertama, descriptive empirical task atau deskriptif kenyataan empiris. Kedua, interpretive task atau gambaran teoritis yang menjelaskan kenyataan-kenyataan empiris menjadi masalah teologis. Ketiga, the normative task atau penggunaan berbagai konsep teologis untuk menafsirkan konteks, sistuasi dan membangun ajaran dari suatu praktik yang baik. Keempat, the pragmatic task atau menentukan strategi dari suatu aksi yang direncanakan untuk mempengaruhi serta membarui konteks problematis yang dikaji.

Tahap pertama dan kedua merupakan bagian dari metode penelitian kualitatif. Metode penelitian dilakukan untuk memperoleh data yang valid dengan tujuan dan kegunaan tertentu. ${ }^{8}$ Jenis penelitian yang digunakan ialahjenis penelitian deskriptif analisis dengan menggunakan metode penelitian kualitatif.Sedangkan, tahap ketiga dan keempat digunakan untuk membangun konstruksi teologis. Pada bagian ini terdapat tindakan-tindakan praksis yang dapat digunakan oleh pihak gereja. Dengan kata lain, tahap ketiga dan keempat akan menjelaskan cara-cara untuk melakukan tindakan advokasi gereja.

Penelitian ini dilakukan di dua lokasi, yakni di Pelabuhan Ambon dengan alasan untuk melihat sistem kerja kaum buruh dan Sinode GPM. Dalam hal ini, peneliti lebih fokus pada masalah-masalah ketidakadilan yang dihadapi oleh kaum buruh di Pelabuhan Ambon secara khusus pada pembagian upah kerja dan tunjangan kesejahteraan buruh. Ada beberapa teknik pengumpulan data yang akan digunakan, yakni pertama, wawancara. Wawancara merupakan teknik pengumpulan data yang dilakukan secara berhadapan dengan informan sehingga dapat memperoleh informasi dengan leluasa. ${ }^{9}$ Teknik wawancara akan dilakukan di kantor Pelabuhan Ambon dan Sinode GPM. Kedua, observasi. Dalam hal ini, penulis akan mengamati proses sistem kerja bongkar muat kaum buruh di Pelabuhan Ambon. Ketiga, dokumentasi. Pada

\footnotetext{
${ }^{7}$ John Liku-Ada, Solidaritas dalam Masyarakat Majemuk: Tinjauan dari Perspektif Ajaran Sosial Gereja dalam buku Menerobos Pintu Sempit (Yogyakarta: Kanisius, 2009), 129-134.

${ }^{8}$ Sugiyono, Metode Penelitian Kuantitatif, Kualitatif dan R\&D (Bandung: Alfabeta, 2013), 2.

9 John W. Creswell, Research Design: Pendekatan Kualitatif, Kuantitatif, dan Mixed (Yogyakarta: Pustaka Pelajar, 2010), 267.
} 
penelitian ini, penulis akan melakukan studi dokumentasi dengan menggunakan fotofoto dan video terkait apa yang akan diteliti. ${ }^{10}$ Secara khusus, penulis akan menggunakan foto-foto terkait proses kerja kaum buruh di Pelabuhan Ambon. Keempat, Studi Pustaka. Dalam penelitian ini, penulis akan melakukan studi pustaka guna memperoleh landasan teori melalui buku, literatur atau catatan terkait dengan penelitian yang dilakukan.

\section{Pembahasan}

\section{Ketidakadilan yang dihadapi oleh Kaum Buruh}

Sistem kerja yang dimiliki oleh pihak koperasi ialah sistem bergilir. Misalnya, sebuah kapal yang masuk dan berlabuh di pelabuhan memiliki jumlah muatan yang besar dengan kapasitas dua palka atau ruang penyimpanan, maka kelompok kerja yang ditugaskan sebanyak empat kelompok, yakni kelompok kerja 1 dan 2 sebagai stevedoring atau yang bekerja di atas kapal; dan kelompok kerja 3 dan 4 sebagai cargodoring atau yang bekerja di dermaga. Kedua kelompok kerja tersebut memiliki tarif pembayaran upah yang sama. Tarif per palka dikenakan 100 sehingga dibagi menjadi 50 kepada kelompok kerja cargodoring dan 50 bagi kelompok kerja stevedoring. Hasil pembagian tersebut kemudian dikalikan dengan tarif upah kaum buruh yang telah ditetapkan oleh pihak koperasi, sehingga dikalkulasikan menjadi 50 x Rp. Rp.241.000 = Rp. 12.050.000. Hasil tersebut kemudian dibagi menjadi 17 bagian yang terdiri dari seorang mandor yang memperoleh 2 bagian dan 15 anggota kerja, sehingga setiap anggota dapat memperoleh upah sebesar Rp. 709.000. Upah tersebut diberikan pada hari yang sama saat bekerja. Akan tetapi, besarnya upah kerja yang diberikan juga tergantung pada jumlah kapal yang melakukan operasi bongkar muat.

Kelompok kerja buruh di Pelabuhan Ambon melakukan pekerjaan bongkar muat sebanyak dua kali dalam sebulan. Oleh sebab itu, mereka memperoleh upah rata-rata sebanyak Rp. 709.000 × 2 = Rp. 1.418.000. Akan tetapi, menurut beberapa anggota buruh, pembagian upah kerja di lapangan terkadang tidak merata. Hal ini dikarenakan oleh pembagian upah yang dimanipulasi oleh pihak tertentu, yakni mandor kelompok buruh. Pernyataan ini didukung juga oleh buruh yang lain bahwa upah yang diberikan terkadang tidak sebanding dengan pekerjaan yang dilakukan. Dalam hal ini, jumlah uang yang diterima oleh para pekerja tidak sebanding dengan jumlah pekerjaan yang dilakukan. Bagi Marx, upah yang diperoleh sangatlah tidak sepadan dan hal tersebut jelas-jelas tidak adil. Pekerja seharusnya mampu menjamin kebutuhan para pekerja yang telah mengumpulkan kekayaan bagi pemilik. ${ }^{11}$ Dengan demikian, keadilan menurut Marx ialah memberikan kepada setiap orang apa yang mereka butuhkan dan meminta setiap orang hanya apa yang dapat mereka lakukan. Berdasarkan realitas kaum buruh, hal ini menunjukan bahwa kaum buruh sementara berada dalam situasi yang tidak adil.

${ }^{10}$ Creswell, Research Design, 270.

11 Julian Baggini, Lima Tema Utama Filsafat: Filsafat Pengetahuan, Filsafat Moral, Filsafat Agama, Filsafat Pikiran, dan Filsafat Politik (Jakarta: Teraju, 2004), 201. 
Seseorang dapat dikatakan adil jika ia memperoleh apa yang patut ia dapatkan. Dalam hal ini, kaum buruh sementara mengalami ketidakadilan distributif. Keadilan distributif lebih berfokus pada hubungan antar masyarakat dengan perorangan. Dalam hal ini, masyarakat sebagai pihak yang memberikan atau membagi-bagikan (subjekkewajiban), sedangkan perorangan atau anggota masyarakat sebagai penerima (subjekhak). ${ }^{12}$ Oleh sebab itu, kenyataan yang dihadapi oleh kaum buruh menunjukan situasi ketidakadilan di mana mereka tidak mendapatkan perlakuan dan pembayaran sesuai dengan jasa-jasa yang telah mereka lakukan. Artinya bahwa tenaga yang telah dikeluarkan oleh kaum buruh harus setara dengan upah kerja yang diberikan kepada mereka. Apabila hal tersebut berjalan sesuai dengan ketentuan yang ada, maka keadilan distributif dapat ditegakan bagi kaum buruh.

Dalam proses kerja juga terdapat indikasi beberapa mandor tidak transparan pada bagian keuangan sehingga kaum buruh hanya menerima upah tanpa mengetahui perinciannya secara detail. Salah seorang pegawai operasional juga mengatakan bahwa apabila terjadi manipulasi pembagian upah kerja oleh pihak-pihak tertentu, maka mereka akan dipanggil oleh ketua koperasi dan akan diberikan peringatan. ${ }^{13}$ Jika tindakan tersebut terjadi lebih dari sekali maka mereka akan dilaporkan kepada pihak yang berwajib atau kepolisian. Akan tetapi, sejauh ini pihak koperasi masih saja memberikan peringatan secara berulang kali tanpa ada pelaporan terhadap tindakan mandor kepada pihak berwajib atau kepolisian. Menanggapi persoalan di atas, nampak bahwa peringatan yang diberikan oleh pihak koperasi dan peraturan untuk menindaklanjuti di pihak berwajib atau kepolisan menjadi bagian dari penegakan keadilan vindikatif. Dalam hal ini, keadilan vindikatif merupakan salah satu bentuk penegakan keadilan dengan cara memberikan hukuman atau denda kepada pihak yang bersangkutan.

Akan tetapi, dalam pelaksanaannya, pihak Pelabuhan Ambon belum maksimal menegakan keadilan tersebut. Pihak Pelabuhan Ambon masih berulang kali memberikan peringatan dan tidak memberikan sanksi hukum terhadap tindakan kejahatan yang dilakukan. Dengan cara seperti itu, maka masih ada kemungkinan bagi para mandor untuk melakukan kesalahan yang sama secara berulang kali. Selain itu juga nampak bentuk ketidakadilan yang terjadi ialah ketidakadilan struktural. Kekuasaan yang dimiliki oleh para mandor membuat mereka menguasai segala sesuatu yang ada di bawah kepemimpinanya. Secara struktural, mandor berada pada posisi teratas dan buruh berada pada posisi di bawah. Oleh sebab itu, mandor melakukan hal-hal yang sangat bertentangan dengan martabat kaum buruh.

\footnotetext{
${ }^{12}$ Sutarno, "Makna dan Tuntutan Keadilan” dalam Bina Darma Pembangunan untuk Keadilan, Nomor 13 Tahun Ke-4 (1986), 11-12.

${ }^{13}$ Hasil Wawancara dengan LW (Pegawai di TKBM Pelabuhan Ambon) pada tanggal 20 Februari 2019.
} 
Berdasarkan Upah Minimum Provinsi Maluku dan Upah Minimum Kota Ambon, upah seorang pekerja ialah Rp.2.436.077 per bulan. ${ }^{14}$ Penetapan Upah Minimum Provinsi didasarkan pada nilai Kebutuhan Hidup Layak dengan mempertimbangkan produktivitas, pertumbuhan ekonomi dan usaha paling marjinal. Apabila dibandingkan dengan upah yang didapatkan oleh kaum buruh di Pelabuhan Ambpn sebesar Rp. 1.418.000 per bulan, maka dapat dikatakan bahwa upah tersebut belum setara dengan standarisasi yang telah ditetapkan. Pemberian upah kerja kepada kaum buruh bukan lagi untuk mengurangi kemiskinan sebagai tujuan utama penetapan Upah Minimum Provinsi, melainkan justru menambah jumlah orang yang hidup dalam keadaan miskin. Dengan demikian, dapat dikatakan bahwa kaum buruh memperoleh upah kerja secara tidak adil dan tidak merata antara satu dengan yang lain. Kenyataan seperti ini tentu akan mempengaruhi kesejahteraan kaum buruh.

Selain itu, kaum buruh Pelabuhan Ambon juga mengalami ketidakadilan berdasarkan tunjangan kesejahteraan yang diterima. Tunjangan kesejahteraan kaum buruh diperoleh melalui 15\% dari upah kerja kaum buruh. Ada beberapa tunjangan yang diberikan kepada kaum buruh, yakni Tunjangan Hari Raya, Tunjangan Kesehatan, Tunjangan beasiswa untuk anak-anak berprestasi, Tunjangan Pakaian Dinas, dan Tunjangan Pendidikan dan Pelatihan atau Diklat. Berdasarkan tunjangan-tunjangan tersebut terdapat beberapa tunjangan yang diberikan namun tidak sepenuhnya mensejahterakan kaum buruh, di antaranya ialah Tunjangan Hari Raya atau THR dan Tunjangan Kesehatan.

Pembagian Tunjangan Hari Raya biasanya dilakukan seminggu sebelum hari raya. Hal ini telah menjadi ketetapan dalam Undang-undang Nomor 78 tahun 2015 Pasal 7. Tunjangan yang diberikan oleh pihak pelabuhan dapat berupa uang tunai dan juga berupa natura seperti beras dan ayam. Akan tetapi, pembagian tersebut diberikan tergantung keadaan perekonomian pelabuhan. Oleh sebab itu, ketika perekonomian menurun maka kaum buruh hanya dapat menerima salah satu tunjangan, yakni berupa uang atau natura. Hal ini menunjukan bahwa secara legalis, pihak pelabuhan sudah membagikan tunjangan hari raya kepada kaum buruh. Itu berarti pihak pelabuhan telah berupaya untuk mewujudkan kesejahteraan dan kepentingan bersama. Akan tetapi secara distributif, apa yang menjadi hak kaum buruh untuk memperoleh tunjangan hari raya tidak didapatkan seutuhnya oleh mereka. Hal ini berarti bahwa pihak pelabuhan belum maksimal menerapkan peraturan yang ditetapkan oleh menteri terkait tata cara pembayaran tunjangan hari raya. Dengan demikian, nampak jelas bahwa pihak Pelabuhan Ambon kurang menerapkan keadilan distributif terhadap jasa kaum buruh dan eksistensi mereka masih tetap berada pada situasi yang tidak adil dan belum sejahtera.

Selain itu, setiap anggota buruh memiliki hak untuk memperoleh perlindungan kesehatan. Pihak pelabuhan menjamin perlindungan tersebut melalui tunjangan

\footnotetext{
${ }^{14}$ Keputusan Gubernur Maluku Nomor 186A Tahun 2018 tentang Penetapan Upah Minimum Kota Ambon Tahun 2019.
} 
kesehatan diberikan kepada anggota buruh, istri dan satu orang anak. Tunjangan kesehatan yang diberikan berupa BPJS Ketenagakerjaan, asuransi kecelakaan dan kematian. Pemberian tunjangan kesehatan menunjukan bahwa pihak Pelabuhan Ambon sudah memiliki perhatian khusus terhadap jaminan kesehatan anggota buruh. Hal ini berarti bahwa pihak pelabuhan juga ingin mempersiapkan dan memperkerjakan buruhburuh dengan kondisi fisik yang sehat. Akan tetapi, seorang buruh lainnya mengatakan bahwa dalam pengalaman kerja selama 10 tahun lebih, tunjangan kesehatan hanya diberikan sebatas pemeriksaan di klinik yang telah tersedia di Pelabuhan Ambon. Hal ini sejalan dengan pengakuan buruh yang lain bahwa tunjangan kesehatan berupa BPJS Ketenagakerjaan selama ini tidak diberikan secara langsung kepada mereka. Kartu BPJS Ketenagakerjaan selama ini dikuasai oleh pihak pegawai operasional, sehingga dalam waktu yang mendesak mereka tidak dapat menggunakannya.

Realitas seperti ini menunjukan bahwa eksistensi kaum buruh sedang berada pada posisi yang dikesampingkan. Kaum buruh tidak diberi kesempatan untuk menguasai apa yang telah menjadi hak mereka. Oleh sebab itu, dapat dikatakan bahwa dibalik kepedulian pihak pelabuhan terhadap kesehatan anggota buruh juga terdapat ketidakadilan yang dapat mempengaruhi kebutuhan jasmani mereka. Pihak operasional memperlambat kaum buruh dalam proses pengurusan administrasi kesehatan. Buruh harus melakukan pengurusan di kantor operasional terlebih dahulu dan setelah itu, ia dapat melanjutkan pengurusan administrasi di klinik Pelabuhan Ambon.

Berdasarkan uraian tunjuangan di atas, maka dapat dikatakan bahwa tidak semua tunjangan hidup diperoleh sepenuhnya oleh kaum buruh. Hal-hal seperti ini tidak mensejahterakan melainkan dapat menjadi ancaman bagi mereka sendiri karena hak tidak dipenuhi.

\section{Keadilan Kristen bagi Kaum Buruh}

Masalah ketidakadilan yang dihadapi oleh kaum buruh merupakan masalah iman yang mengharuskan gereja menyuarakan keadilan dengan berlandas pada keadilan Allah. Dalam hal ini, Alkitab sangat menekankan bahwa keadilan adalah sifat Allah yang dinyatakan untuk membela orang-orang tertindas dan sebagai upaya memelihara kehidupan. ${ }^{15}$ Tercatat dalam kitab Mazmur bahwa "Tuhan menjalankan keadilan dan hukum bagi segala orang yang diperas" (Mzm. 103: 6); "Ia mencintai dan menegakkan keadilan" (Mzm. 99: 4). Dengan demikian, dapat dikatakan bahwa yang menjadi dasar dari keadilan manusia di dunia ini adalah keadilan Allah. ${ }^{16}$ Allah menyatakan keadilan bagi mereka yang lemah dan tertindas sama halnya juga dengan apa yang dialami oleh kaum buruh Pelabuhan Ambon.

Kata "buruh" dalam Alkitab hanya tercatat dalam Perjanjian Baru, yakni Yakobus 5: 1-7, sedangkan pada Perjanjian Lama tidak ditemukan. Pada zaman Surat Yakobus

${ }^{15}$ Einer M. Sitompul, Gereja Menyikapi Perubahan (Jakarta: BPK Gunung Mulia, 2003), 86. 65.

16 Malcoln Brownlee, Tugas Manusia Dalam Dunia Milik Tuhan (Jakarta: BPK Gunung Mulia, 2011), 
ditulis, ada tiga hal yang menjadi simbol bahwa orang itu benar-benar kaya tetapi juga sebagai pelaku kejahatan, yakni orang tersebut menjadi eksportir yang menguasai bahan pokok; pakaian yang digunakan berbeda dengan milik orang lain. Dalam Kisah Para Rasul, pakaian menjadi lambang dari kekayaan dan kemuliaan, khususnya kain ungu, kain lenan; dan memiliki emas, perak, dan permata. ${ }^{17}$ Akan tetapi, semua kekayaan itu tidak mendatangkan kebaikan apapun. Hidup mewah mereka tidak akan bertahan dan juga akan mendatangakan kehancuran bagi mereka. ${ }^{18}$ Hal ini bukan berarti Yakobus mengajak umat membenci kekayaan, melainkan supaya kita tidak menggantungkan pada sesuatu yang tidak akan menolong kita pada akhirnya.

Pada ayat ke-4, Yakobus menyatakan keberpihakannya kepada kaum buruh yang mengalami penindasan paling berat dari kalangan orang kaya. Mereka hidup dalam penderitaan dari hari ke hari. Dalam hal ini, kaum buruh tidak dapat mengajukan protes mereka kepada majikan. Oleh sebab itu, mereka hanya dapat berteriak kepada Tuhan yang mendengar setiap keluhan mereka. ${ }^{19} \mathrm{Hal}$ yang sama juga terjadi pada kehidupan kaum Pelabuhan Ambon. Mereka mengalami penindasan struktural dari pihak-pihak yang berkuasa, namun mereka tidak berani untuk menyuarakannya. Kemungkinan yang terjadi ialah apabila kaum buruh menyuarakan apa yang mereka rasakan, maka pekerjaan mereka menjadi terancam. Selain itu, cara memperoleh kekayaan juga menjadi penting untuk diperhatikan. Artinya bahwa untuk memperoleh kekayaan, maka tindakan yang dilakukan bukanlah dengan cara yang menindas, memeras atau menipu, terutama kepada orang miskin dan lemah. Hal seperti ini juga terjadi dalam realitas hidup kaum buruh, di mana hak-hak hidup mereka dirampas oleh majikan mereka. Tindakan-tindakan tersebut tentu sangat dibenci dan tidak disukai oleh Allah, sebab tidak sejalan dengan kehendaknya untuk mensejahterahkan hidup umat-Nya.

Menanggapi isu-isu ketidakadilan yang dihadapi oleh kaum buruh di Pelabuhan Ambon dan berlandas pada refleksi iman Kristen tentang keadilan, maka ada beberapa pokok penting yang dapat direfleksikan. Pertama, keadilan dapat terjadi ketika upah kerja kaum buruh diperhatikan. Dalam teks Ulangan 24: 14-15 diatur tentang perlakuan terhadap pekerja. Umat Israel khususnya para tuan dilarang untuk menahan upah seorang pekerja atau hamba sebelum matahari terbenam. Menahan upah pekerja harian akan menyebabkan pekerja itu dan keluarganya menderita. Keadilan bagi pekerja harian ditegakkan melalui peraturan ini. Peraturan ini memberikan perlindungan hak dan martabat buruh pada waktu itu. ${ }^{20}$ Dalam konteks masa kini, buruh harus diberi upah berdasarkan jam kerja. Upah buruh Pelabuhan Ambon tidak layak untuk ditahan atau dikorupsi, karena itu akan mempersulit kehidupan para buruh dan keluarganya. Pihak koperasi sebagai pelaku ketidakadilan menyusahkan kehidupan ka-

17 Martin Harun, "Upah yang Kamu Tahan dari Buruh: Jeritan Keadilan dalam Surat Yakobus” dalam LAI, Forum Biblika: Jurnal Ilmiah PopulerNomor 21 Tahun 2007, 28.

18 Harun, "Upah yang Kamu Tahan dari Buruh: Jeritan Keadilan dalam Surat Yakobus”, 29.

${ }^{19}$ Harun, "Upah yang Kamu Tahan dari Buruh: Jeritan Keadilan dalam Surat Yakobus", 29.

${ }^{20}$ Josef Widyatmadja, Yesus dan Wong Cilik: Praksis Diakonia Transformatif dan Teologi Rakyat di Indonesia (Jakarta: BPK Gunung Mulia, 2016) 25. 
um buruh, sehingga kebutuhan hidup mereka tidak dapat terpenuhi secara total. Hal ini telah mengancam martabat kaum buruh sebagai ciptaan Allah yang berhak memperoleh keadilan dalam hidupnya. Menghormati martabat manusia itu berarti sekaligus menghormati kemahadaulatan Allah. Dengan demikian, setiap pekerja sebagai buruh berhak untuk mendapatkan upah kerja yang layak.

Kedua, hubungan kerja yang dibangun dapat mensejahterakan hidup sesama. Hidup sejahtera diartikan sebagai suatu keadaan hidup yang tidak terancam. Tujuan hidup dari kesejahteraan ialah memastikan bahwa setiap orang telah merasakan keadilan Allah. ${ }^{21}$ Selain itu, kesejahteraan bersumber dari Allah sebagai Penguasa Tertinggi yang dinyatakan melalui umat manusia dan sesama. Oleh sebab itu, relasi kerja antara pihak buruh dan majikan harus didasarkan pada suatu bingkai kehidupan inklusif yang bebas dari penindasan. Hubungan-hubungan kerja yang dibentuk harus berlandas pada sumber damai sejahtera, agar kehidupan bersama menjadi bagian dari saling mensejah-terakan antar satu dengan yang lainnya. Semua orang di hadapan Allah memiliki derajat yang sama, karena itu tidak ada orang atau kelompok yang dapat berhak begitu saja untuk menguasai orang lain.

\section{Membangun Peran Advokasi Gereja untuk menciptakan Keadilan}

Gereja sebagai lembaga memiliki peran dan fungsi untuk memperjuangkan hak-hak dasar kebutuhan umat manusia. Gereja dipanggil oleh Allah dan diutus untuk menjadi berkat bagi setiap orang (bdk. Kej. 12: 1-3). Dalam hal ini, Gereja Protestan Maluku terpanggil untuk membebaskan umat dari masalah-masalah kemanusiaan khususnya ketidakadilan. Sangat diharapkan supaya GPM menjadi sumber keadilan yang dapat dinyatakan melalui tindakan-tindakan advokasi agar dapat menciptakan perubahan bagi kehidupan bersama. Tindakan advokasi yang dilakukan dalam konteks bergereja dapat didasarkan pada nilai-niali keagamaan yang berdimensi sosial seperti kebenaran, kesejahteraan, keadilan dan transparasi terhadap segala sesuatu yang dilakukan.

Dalam panggilan advokasi, gereja berperan untuk memberdayakan orang-orang yang lemah, kecil dan terpinggirkan dengan mengacu pada tiga hakekat tugas panggilan gereja. Ketiga hakekat tersebut dapat diuraikan sebagai berikut: ${ }^{22}$

1. Tugas panggilan gereja mengharuskan gereja untuk hidup berpadanan dengan Injil dan berdiri teguh dalam satu roh, dan mengharuskan gereja-gereja sebagai satu tubuh, sehati sepikir berjuang untuk iman yang ditumbulkan oleh berita injil dan mengharuskan mereka saling memahami, memperhatikan dan melayani demi kepentingan bersama (Flp. 1 : 27; 2:4; 1 Kor. 12: 27). Inilah yang menjadi tugas keesaan, yakni membarui, membangun dan mempersatukan gereja.

2. Tugas panggilan gereja adalah menyampaikan Injil Yesus Kristus, yaitu Injil perdamaian sebagai kekuatan Allah yang menyelamatkan dan

21 Jonathan Burnside, God, Justice and Society (New York: Oxford University Press, 2011), 240.

22 PGI, Dokumen Keesaan Gereja: Persekutuan Gereja-gereja di Indonesia 2014-2019 (Jakarta: Gunung Mulia, 2015), 43-44. 
memperdamaikan segala sesuatu dengan Allah (Rm. 1: 16-17; Kol. 1:20). Hal ini berarti bahwa gereja harus memberitakan Injil, yaitu berita tentang Allah Yesus Kristus yang memberlakukan keadilan dan kebenaran-Nya yang menyelamatkan, yang menuntut pertobatan, yang memberikan keadilan-Nya kepada orang-orang miskin dan tertindas, yang mengaruniakan kesejahteraan kepada segala bangsa dan segala makhluk (Luk. 24: 47; Mrk. 16: 15) sebagai bagian dari karya menyeluruh Yesus Kristus yang memperdamaikan dan memulihkan segala sesuatu ke dalam persekutuan yang harmonis dengan Allah dan sesamnya. Inilah tugas pemberitaan atau pekabaran Injil yang menjadi bagian dari keseluruhan misi gereja di dunia ini.

3. Tugas panggilan gereja mengharuskan gereja memerangi segala penyakit, kelemahan dan ketidakadilan dalam masyarakat. Gereja berkewajiban untuk mengusahakan dan memelihara secara bertanggung jawab akan sumbersumber alam dan lingkungan hidup. Inilah tugas pelayanan dalam kasih serta keadilan.

Berdasarkan ketiga poin di atas dan menyikapi persoalan ketidakadilan yang terjadi pada kaum buruh, maka GPM terpanggil untuk menyuarakan dan menyatakan kehendak Allah yang termanifestasi dalam kehidupan bersama. Gereja turut terlibat dalam realitas hidup kaum buruh dan melakukan pembelaan terhadap mereka demi memenuhi tugas dan panggilan gereja yang ada. ${ }^{23}$

Sejauh ini, GPM belum memiliki perhatian kepada masalah kemanusiaan yang dihadapi oleh kaum buruh khususnya yang berada di Pelabuhan Ambon. Hal ini berarti bahwa GPM juga belum melakukan tindakan advokasi di tingkat jemaat, klasis dan sinode terhadap mereka. Oleh sebab itu, dalam upaya melakukan tindakan advokasi terhadap kaum buruh Pelabuhan Ambon, pertama-tama GPM harus menyadari untuk hidup berpadanan dengan Injil Yesus Kristus agar dapat membarui, membangun dan mempersatukan kehidupan bersama. Setelah menyadari semua itu, gereja bertugas untuk menyatakan Injil Yesus Kristus bagi sesama serta memberlakukan keadilan dan kebenaran-Nya yang menyelamatkan dan memberikan keadilan-Nya kepada orangorang miskin yang tertindas.

Ada beberapa peran dan fungsi yang harus dimiliki oleh GPM untuk melakukan tindakan advokasi, yakni pertama, gereja sebagai fasilitator. Dalam hal ini gereja mempersiapkan setiap anggota atau kelompok kaum buruh dengan sejumlah informasi tentang hak-hak hidup mereka, agar mereka tidak mudah dibodohi dengan kebijakan yang mengatur hak hidup mereka. Dengan demikian gereja sudah membuka mata mereka tentang hal-hal yang adil dan benar. Kedua, gereja sebagai mediator. Gereja menjembatani setiap anggota atau kelompok kaum buruh dengan pihak-pihak terkait dalam kepentingan hak-hak hidup mereka. Dalam hal ini, gereja dapat bekerja sama dengan Lembaga-lembaga Swadya Masyarakat dan juga Konfederasi Serikat Buruh Sejahtera Indonesia Wilayah Maluku dengan tujuan untuk memperjuangkan hak hidup kaum buruh yang tertindas. Ketiga, gereja sebagai transformator. Dalam hal ini, gereja menerapkan fungsi edukasi, menjaga perimbangan informasi dan media edukasi yang

\footnotetext{
${ }^{23}$ Hasil Wawancara dengan WP (MPH Sinode GPM) pada tanggal 01 Maret 2019.
} 
berbasis keadilan bagi kehidupan kaum buruh. Dengan demikian, kaum buruh tidak berjalan sendiri dalam dalam memperjuangkan keadilan atas hak-hak hidup mereka, melainkan ada bersama dengan pihak gereja sebagai agen advokasi. Tindakan advokasi yang dilakukan menjadi sangat luas sebagai tindakan membela atau to defend, memajukan atau to prmote, menciptakan atau to create, dan mengubah atau to change. Tindakan-tindakan seperti ini menunjukan bahwa GPM dapat memposisikan keberpihakannya untuk membangun kemanusiaan secara bersama-sama dalam relasi yang utuh dengan memandang sesama sebagai subjek-subjek dan bukan subjek-objek. Pada titik seperti inilah lahir gerak bersama untuk membangun rasa kemanusiaan yang berjalan sebagai panggilan teologis yang berkelanjutan.

Berkaca pada realitas kehidupan kaum buruh yang mengalami berbagai bentuk ketidakadilan yang telah diuraikan pada bagian sebelumnya dan ditinjau dari peran dan fungsi gereja dalam melakukan tindakan advokasi, maka ada beberapa langkah praktis yang dapat dilakukan, yakni pertama, gereja membentuk sebuah tim advokasi dengan melibatkan orang-orang yang memiliki kemampuan di bidang hukum. Tujuan pembentukkan tim ialah untuk membangun kerja sama yang dapat menciptakan perubahan dari berbagai aspek demi memperoleh keadilan atas hak-hak hidup kaum buruh. Kedua, gereja melakukan kerja sama dengan pihak pemerintah atau lembaga terkait untuk mempermudah penyelesaian persoalan ketidakadilan. Ketiga, gereja membangun kerja sama dengan pemimpin agama lain, khususnya agama Islam dengan mengingat bahwa anggota buruh Tenaga Kerja Bongkar Muat Pelabuhan Ambon terdiri dari buruh beragama Islam dan Kristen. Keempat, melakukan sosialisasi dengan tujuan untuk menyadarkan, menguatkan dan mempertahankan hak-hak hidup kaum buruh sehingga memperoleh transformasi dalam cara berpikir.

Dalam hal ini, pihak gereja dengan bantuan orang-orang yang memiliki kemampuan di bidang hukum dapat mensosialisasikan undang-undang yang berkaitan dengan sistem perburuhan, seperti Undang-undang Nomor 13 Tahun 2003 tentang Ketenagkerjaan, Undang-undang Nomor 78 Tahun 2015 tentang Pengupahan, Peraturan Pemerintah Nomor 46 Tahun 2015 tentang Jaminan Hari Tua dan sebagainya. Materi-materi ini disosialisasikan kepada kaum buruh dengan mengingat bahwa tidak semua kaum buruh telah mengetahui undang-undang yang selama ini menjadi payung untuk melindungi hak-hak hidup mereka. Kelima, gereja mengupayakan pertemuan bersama untuk membina rasa saling menopang dan berbagi pengalaman terkait pekerjaan yang ditekuni selama ini. Pertemuan ini bertujuan untuk saling peduli dan saling membantu untuk menemukan jalan keluar dari persoalan yang dihadapi. Keenam, gereja dapat melakukan tindakan advokasi terhadap kaum buruh melalui media massa dan elektronik.Ketujuh, gereja mendampingi kaum buruh dalam upaya melakukan negosiasi, mediasi dan bermusyawarah dengan pihak-pihak terkait. 


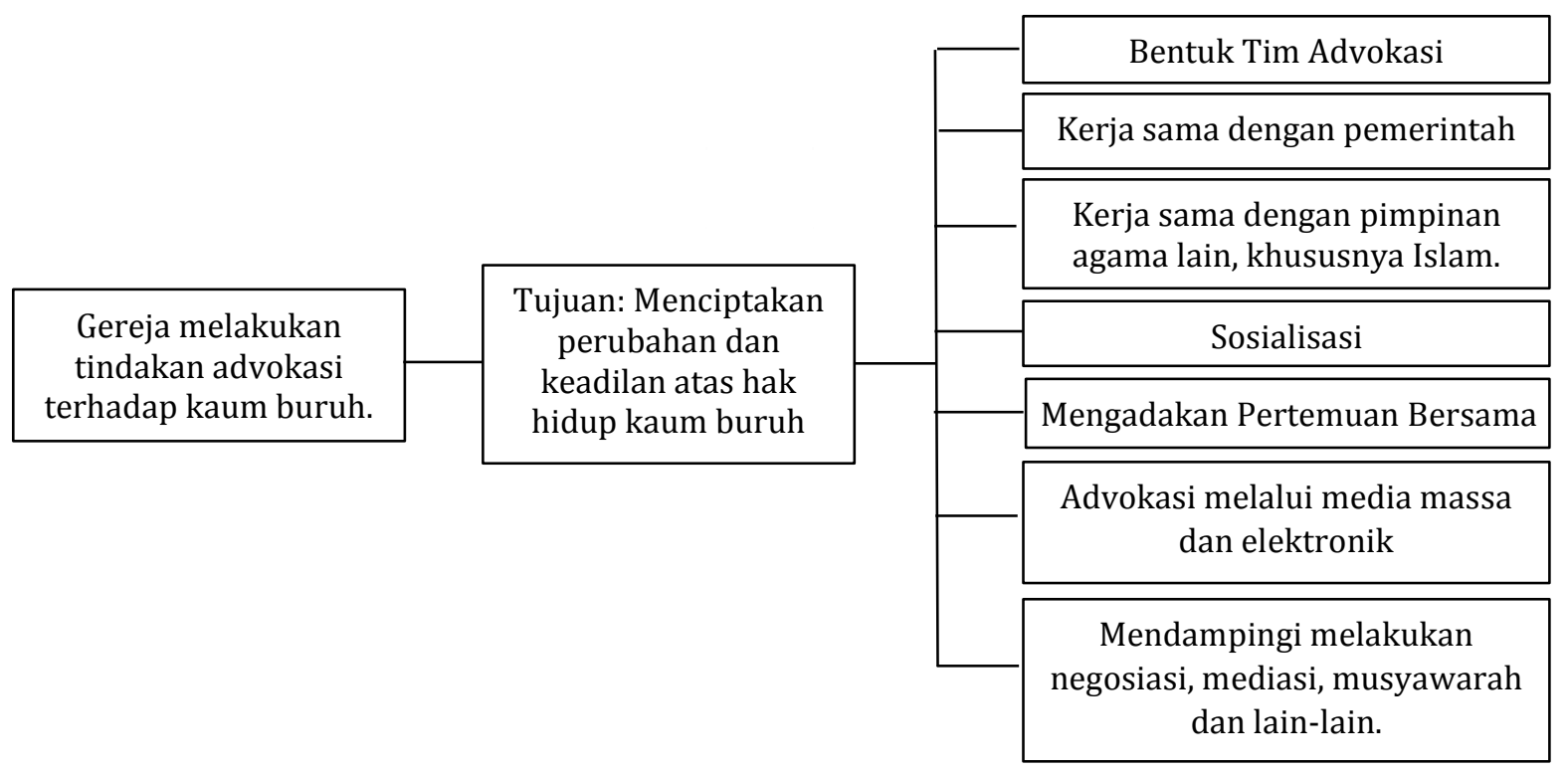

Dalam mengembangkan perannya, pertama-tama gereja harus cermat dan dan teliti untuk membedah persoalan kaum buruh. Gereja mengumpulkan informasi-informasi terkait persoalan kaum buruh dan menempatkan masalah pada porsinya agar dapat membantu gereja untuk menentukan sikapnya sebagai institusi. Kemudian gereja melakukan analisis sosial yang mendalam terkait masalah tersebut. Setelah itu, melalui Biro Hukum yang berada di bawah Departement Pelayanan Kasih, Gereja Protestan Maluku dapat memaksimalkan peran advokasinya bagi kaum buruh yang mengalami persoalan ketidakadilan atas hak-hak hidup mereka. Tindakan advokasi gereja dapat diawali dengan menyiapkan alternatif pemecahan masalah melalui jalur hukum; mempengaruhi pendapat umum dengan cara mengadvokasi melalui media massa dan elektronik; memengaruhi pembuat keputusan dengan cara melakukan negosiasi dan mediasi; mengadakan pembelaan dengan mengacu pada ajaran-ajaran gereja; dan tetap mempertahankan pembelaan tersebut untuk menciptakan transformasi yang adil.

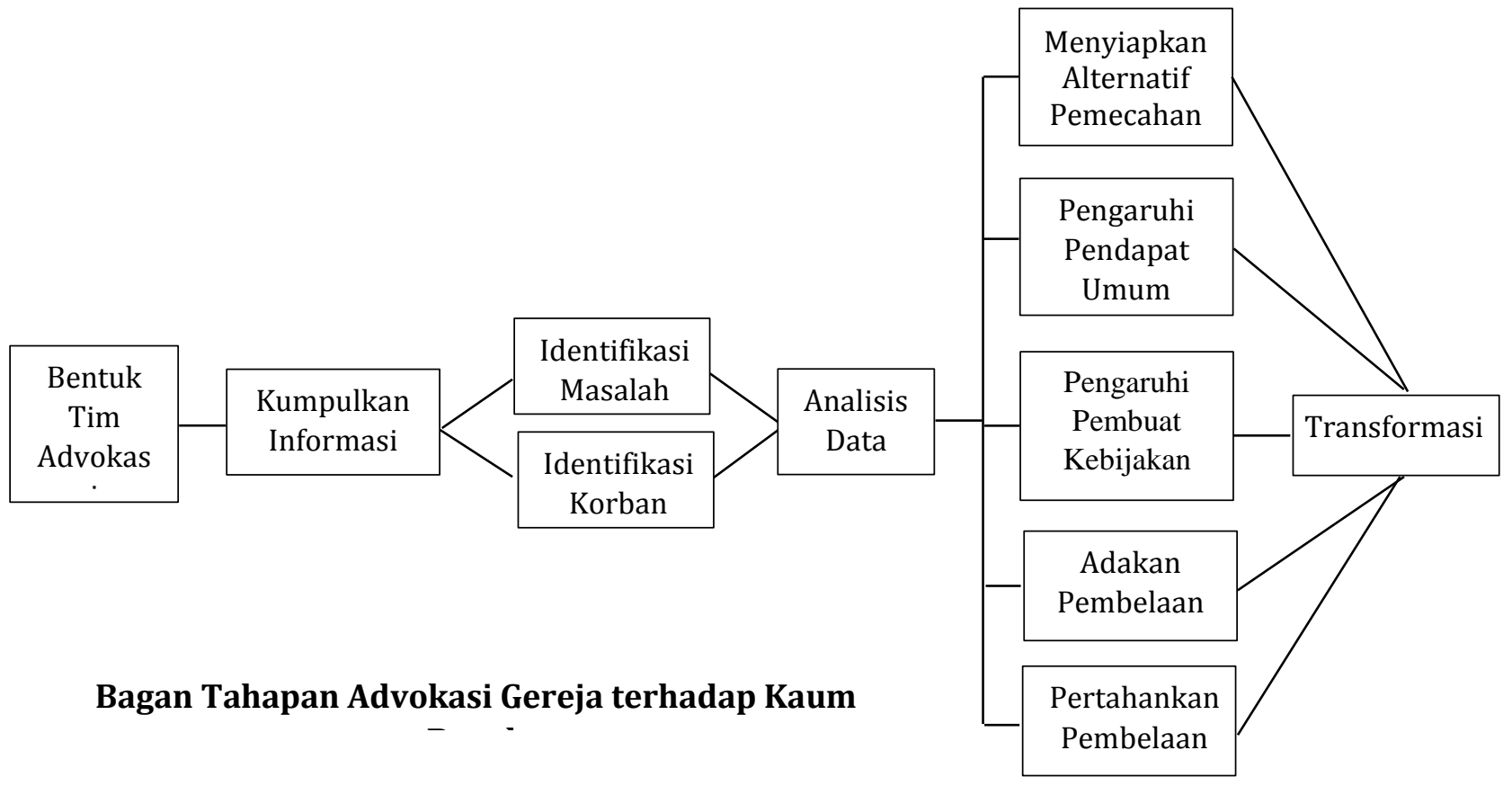


Ajaran Gereja Protestan Maluku menegaskan bahwa gereja dan pemerintah yang berada di bawah payung negara dapat bekerja sama dalam beberapa hal, yakni untuk mengusahakan kesejahteraan manusia dan semua ciptaan (Yer. 29: 7); menegakan hukum, keadilan, kebenaran, dan hak asasi manusia (Am. 5: 15 dan 24); dan memperkuat masyarakat berkeadaban (Rm. 12: 9-21; 13: 1-7). Oleh sebab itu, dalam upaya untuk melakukan tindakan advokasi gereja terhadap kaum buruh, maka gereja dan pemerintah dapat bergandeng tangan untuk mensejahterakan kehidupan bersama. ${ }^{24}$ Gereja bertugas untuk menyampaikan suara kenabian apabila negara atau pemerintah telah menyalahgunakan wewenang dan kekuasaan yang ada padanya. Hal ini didukung juga dengan cara mendoakan para pemimpin agar mereka dapat melaksanakan pemerintahan sesuai dengan kehendak Allah bagi kesejahteraan rakyat.

Tindakan advokasi yang dilakukan oleh pihak GPM tidak hanya harus berfokus pada kaum buruh yang beragama Kristen, tetapi juga kepada kaum buruh yang beragama Islam. Hal ini dilakukan dengan mengingat bahwa kaum buruh tidak hanya terdiri dari umat Kristen melainkan juga umat Muslim. Dengan demikian, tindakan advokasi yang dilakukan oleh gereja tidak bersifat eksklusif melainkan inklusif. Ajaran GPM juga menegaskan bahwa keberadaan agama lain harus diakui dan diterima sebagai agama yang juga mengajarkan kebenaran dan kebaikan kepada para penganutnya. GPM meyakini Allah di dalam Yesus Kristus adalah Allah yang Maha Kuasa, yang juga dapat berkarya dalam cara yang luas, termasuk berkarya dan menyelamatkan umat manusia melalui agama-agama lain. ${ }^{25}$ Berdasarkan pemahaman seperti ini maka GPM terpanggil untuk menyatakan tindakan advokasi kepada setiap orang tanpa memandang latar belakang identitas keagamaan. GPM mengadvokasi bukan karena identitas agama melainkan pada kemanusiaan anggota kaum buruh yang tertindak akibat berbagai tindakan ketidakadilan.

Ada beberapa landasan yang dapat menolong gereja dan agama lain membangun kerja sama untuk melakukan advokasi, yakni pertama, gereja mengakui bahwa semua manusia diciptakan menurut gambar dan rupa Tuhan (Kej. 1: 26) Tuhan memberkati mereka dan memberikan nama mereka "manusia" kepada mereka (Kej. 5: 2). Oleh karena itu, semua manusia adalah sesama manusia. Kedua, Tuhan memperhatikan semua manusia berdasarkan kasih karunia-Nya kepada mereka. Dalam hal ini, kasih Tuhan tidak hanya terbatas pada bangsa Israel atau umat Kristen melainkan meliputi semua manusia. ${ }^{26}$ Dengan demikian, jika seorang Kristen bertemu dengan seorang yang beragama lain, maka ia bukan bertemu dengan seorang lawan atau musuh, tetapi dengan saudara yang dikasihi Tuhan Allah.

\footnotetext{
${ }^{24}$ Ajaran Gereja Protestan Maluku Nomor 130 tentang Hubungan Gereja dan Negara.

${ }^{25}$ Ajaran Gereja Protestan Maluku Nomor 179-190 tentang GPM dan Agama Lain.

${ }^{26}$ A. A. Yewangoe, Agama dan Kerukunan (Jakarta: BPK Gunung Mulia, 2001), 75-76.
} 


\section{Kesimpulan}

Kaum buruh di Pelabuhan Ambon mengalami beberapa masalah ketidakadilan yang mengakibatkan kehidupan mereka menjadi tidak sejahtera. Masalah-masalah tersebut adalah pembagian tarif upah kerja yang tidak merata dan tidak memperoleh tunjangan kesejahteraan sepenuhnya. Artinya bahwa dibalik kebijakan pemberian tunjangantunjangan kesejahteraan terdapat berbagai berbagai tindakan penyimpangan yang menghalangi kesejahteraan kaum buruh. Upah yang diperoleh kaum buruh tidak sebanding dengan tenaga yang dikeluarkan. Akan tetapi, mereka tetap berusaha untuk menerima upah tersebut sebagai penunjang kebutuhan hidup mereka. Hal ini mengakibatkan kaum buruh tidak dapat memenuhi kebutuhan hidup secara utuh, sehingga terkadang mereka harus mencari penghasilan tambahan. Dengan demikian, eksistensi kaum buruh masih berada dalam situasi yang tidak adil dan tidak sejahtera. Berdasarkan persoalan ketidakadilan yang dihadapi oleh kaum buruh di Pelabuhan Ambon, maka gereja terpanggil untuk membela setiap orang yang terperangkap dalam tindakan yang tidak adil. Sejauh ini, GPM belum memiliki perhatian terhadap masalah kemanusiaan yang dihadapi oleh kaum buruh. Akan tetapi, dalam tugas panggilan gereja sebagai agen advokasi, maka GPM dapat melakukan tindakan advokasi dengan menjadikan ajaran-ajaran Yesus Kristus sebagai dasar utama. Selain itu, gereja juga dapat membangun kerja sama dengan pemerintah agar tindakan advokasi dapat bersifat holistik dan tidak eksklusif. Gereja melakukan tindakan advokasi atas dasar tiga peran dan fungsi, yakni fasilitator, mediator dan transformator. Dengan demikian, akhir dari proses advokasi yang dilakukan pihak gereja ialah sasaran advokasi dapat memperoleh hak-hak hidup yang adil dan sejahtera.

\section{Referensi}

Aritonang, Jan. dan Ateria Aritona. Mereka juga Citra Allah: Hakikat dan Sejarah Diakonia temasuk bagi yang Berkeadaan dan Berkebutuhan Khusus: Buruh, Migran dan Pengungsi, Penyandang Disabilitas, LGBT. Jakarta: BPK Gunung Mulia, 2017.

Baggini, Julian. Lima Tema Utama Filsafat: Filsafat Pengetahuan, Filsafat Moral, Filsafat Agama, Filsafat Pikiran, dan Filsafat Politik. Jakarta: Teraju, 2004.

Banawiratma, J. B. Hidup Menggereja Kontekstual. Yogyakarta: Kanisius, 2000.

Brownlee, Malcolm. Tugas Manusia Dalam Dunia Milik Tuhan. Jakarta: BPK Gunung Mulia, 2011.

Burnside, Jonathan. God, Justice and Society. New York: Oxford University Press, 2011.

Creswell, John W. Research Design: Pendekatan Kualitatif, Kuantitatif, dan Mixed. Yogyakarta: Pustaka Pelajar, 2010.

Darmaputera, Eka. Iman dalam Perbuatan. Jakarta: BPK Gunung Mulia, 2015.

Halili, Toha. Majikan dan Buruh.Jakarta: Rineka Cipta, 1987.

Harun, Martin. "Upah yang Kamu Tahan dari Buruh: Jeritan Keadilan dalam Surat Yakobus" dalam LAI, Forum Biblika: Jurnal Ilmiah PopulerNomor 21 Tahun 2007: 23-33.

Liku-Ada, John. Solidaritas dalam Masyarakat Majemuk: Tinjauan dari Perspektif Ajaran Sosial Gereja dalam buku Menerobos Pintu Sempit. Yogyakarta: Kanisius, 2009. 
PGI, Dokumen Keesaan Gereja: Persekutuan Gereja-gereja di Indonesia 2014-2019. Jakarta: Gunung Mulia, 2015.

Prasetyo, Alis Windu. "Berkubang dalam Lumpur, Bekerja Bersama Orang Miskin" Wajah Keterlibatan Sosial Gereja Ganjuran", dalam Jurnal Teologi Volume 3 Nomor 1 Tahun 2014.

Retnowati. "Jaringan Sosial Gereja Kristen Jawi Wetan dengan Pondok Pesantren di

Malang Jawa Timur" dalam Journal of Science and Religion Volume 20 Nomor 1 Tahun 2013.

Sitompul, Einer M. Gereja Menyikapi Perubahan. Jakarta: BPK Gunung Mulia, 2003.

Soepomo, Iman. Pengantar Hukum Perburuhan. Jakarta: Djambatan, 1980.

Sugiyono. Metode Penelitian Kuantitatif, Kualitatif dan R\&D. Bandung: Alfabeta, 2013.

Widyatmadja, Josef. Yesus dan Wong Cilik: Praksis Diakonia Transformatif dan Teologi Rakyat di Indonesia. Jakarta: BPK Gunung Mulia, 2016.

Yewangoe, A. A. Agama dan Kerukunan. Jakarta: BPK Gunung Mulia, 2001.

\section{Sumber Lain}

Ajaran Gereja Protestan Maluku

Keputusan Gubernur Maluku Nomor 186A Tahun 2018 tentang Penetapan Upah Minimum Kota Ambon Tahun 2019. 